Garnett, M. (2003) 'A Question of Definition? Ideology and the Conservative Party 1997-2001, in M. Garnett and P. Lynch (eds.), The Conservatives in Crisis, Manchester: Manchester University Press, pp. 107-124.

Gray, J. (1995) 'The Undoing of Conservatism, in Enlightenment's Wake: Politics and Culture at the Close of the Modern Age, London: Routledge, pp. 87-119.

Green, E.H.H. (2002) Ideologies of Conservatism, Oxford: Oxford University Press.

Greenleaf, W.H. (1983) The British Political Tradition Volume Two: The Ideological Heritage, London: Methuen.

Hayek, F.A. (1960) The Constitution of Liberty, London: Routledge and Kegan Paul.

Honderich, T. (1989) Conservatism, 1st edn, Harmondsworth: Penguin.

Kruger, D. (2005) 'Pyrrhic defeat', New Statesman, 11th Apr, 2005, pp. 54-56.

Miller, D. (1999) Principles of Social Justice, Cambridge MA: Harvard University Press.

O'Hara, K. (2005) After Blair: Conservatism Beyond Thatcher, Cambridge: Icon Books.

Powell, J.E. (1990) 'Theory and Practice, in G.M.K. Hunt (ed.) Philosophy and Politics, Cambridge: Cambridge University Press, pp. 1-9.

Roy, O. (2004) Globalized Islam: The Search for a New Ummah, New York: Columbia University Press.

Kieron O'Hara

University of Southampton, UK

\title{
Isaiah Berlin: Liberty and Pluralism
}

George Crowder

Polity Press, Cambridge, 2004, xii $+230 \mathrm{pp}$.

ISBN: 0745624774.

Contemporary Political Theory (2006) 5, 358-360. doi:10.1057/palgrave.cpt.9300245

The revival of interest in the work of Isaiah Berlin is, perhaps, one of the more curious aspects of modern political thought. Apart from a short book on Karl Marx he did not write a sustained work of political philosophy as did, for example, his contemporary Michael Oakeshott, nor anything systematic to compare with John Rawls's $A$ Theory of Justice. Berlin was primarily an essayist and those essays, usually dictated rather than written, often seem to be repetitive and lacking in development. Nevertheless, despite the criticisms, Berlin has a large and influential body of supporters. Indeed, some go so far as to describe him as the most important political thinker of our time.

George Crowder's intention, he states, is to provide an accessible introduction to Berlin's work as well as to the criticisms that work has provoked. Most usefully Crowder has looked at the development of Berlin's ideas by others, such as John Gray, and he has, in the final chapter offered an appreciation of his significance both within the Liberal tradition and in 
political thought more generally. He has succeeded in this aim and this book will be a more than useful work for anyone looking for such a guide.

While it is probably true to say that during the major part of his lifetime Berlin was best known for his Inaugural lecture 'Two concepts of liberty' it seems that towards the end of his life and since his death most attention has been focussed on his idea of 'pluralism'. Making use of the distinction that Berlin popularized, it seems that Berlin was an intellectual hedgehog pretending to be a fox. The basic idea that it is now generally accepted dominates his thought is the opposition between value pluralism and monism. In Crowder's view, the idea of pluralism and the defence of negative liberty must be understood in terms of 'a single, dominant project, namely the liberal struggle against 20th century totalitarianism'. Berlin's defence of pluralism is grounded in a partisan struggle against totalitarianism, but most notably against that of the left. If it is true, as Crowder suggests, that this is the central theme, then Berlin was not altogether consistent in his diagnosis of the origins and nature of the totalitarian threat.

There are three related themes, Crowder argues, that stand out in Berlin's work. Contrary to some of Berlin's critics he argues that there is also a discernible development in these ideas. The first theme is 'the betrayal of freedom'. This is one of the origins of totalitarian thought. This occurs, principally, where positive liberty is distorted. The second theme is the conflict between the Enlightenment and its enemies. This conflict is complicated in Berlin's account because, while Romantic criticisms of the Enlightenment are a source of modern irrationalism, the thinkers of the Enlightenment are also responsible, to a large extent, for a utopian faith in reason that has also contributed to some of the horrors of modernity. One of the difficulties in understanding Berlin, it is often remarked, comes from the way in which he wrote the history of ideas. Berlin was committed to giving an imaginative reconstruction that was as sympathetic as possible to the ideas of the thinkers whose ideas he dissected. Unfortunately, the result is that it is often very difficult to say with certainty who is talking: is it Berlin or is it, for example, Vico or Hamann? Or do all the thinkers whom Berlin discusses, as Ernest Gellner once remarked, sound remarkably like Berlin himself? However, despite these problems it is now clear that as far as Berlin was concerned, totalitarianism has its roots both in the ideas of the Enlightenment and in the ideas of its critics. Berlin was not altogether consistent here. Although he did look for and find the roots of totalitarianism in the ideas of past thinkers as did many of his contemporaries, such as Karl Popper, Friedrich Hayek, and JLTalmon, Berlin at other times was more insistent upon the idea that the political thought of the 20th century has a distinct character that sets it apart from that of earlier times. 
The third theme is that of the opposition between value pluralism and monism. This is the theme that has had the most impact upon political theorists since Berlin's death. Berlin himself did not produce a detailed account of just what he meant by value pluralism and it has been left to others to explore the nature and implications of this idea. He did not say much about the conceptual distinction between incomparability and incommensurability and was less than convincing upon the implications of value pluralism for practical reason. The thesis of pluralism has been accused of being no more than a version of relativism, while some of those who are sympathetic to the idea do not see it as being particularly original. Berlin reluctantly admitted to the existence of intellectual precursors such as Max Weber.

The most troubling problem, perhaps, for Berlin here was that of the relationship between pluralism and liberalism. Does pluralism entail or does it undermine liberalism?

Crowder makes a good case for placing Berlin within a particular intellectual and political context. Certainly, his liberal pluralism does not exactly produce a strong theoretical argument but it does produce a persuasive rhetoric against the search for political and moral perfection. One could argue that if pluralism is true, then one of its consequences is to effect a limit upon the pretensions of theory.

Why do so many, despite all the criticisms, still find Berlin so interesting? One reason is to be found in the contemporary recognition of what Rawls has called 'the fact of pluralism' as a serious problem. But, perhaps, more significantly Berlin represents a historically sensitive way of writing political theory that owes nothing to the abstracted utopianism of much recent normative theorizing while, at the same time, in taking the central vision of thinkers seriously, avoids the reductionism and superficiality of much political science.

Peter Lassman

Department of Political Science and International Studies, The University of Birmingham, UK

\section{The Question of Women in Chinese Feminism}

Tani E Barlow

Duke University Press, London, 2004, $x+484 p p$.

ISBN: 0822332701.

Contemporary Political Theory (2006) 5, 360-362. doi:10.1057/palgrave.cpt.9300246

The question of women in Chinese feminism is a superbly argued exercise in feminist historiography that analyses the Chinese feminist project of establishing and defining the subject of women in 20th century modern Chinese 